\title{
Factors affecting goat milk fat yield
}

Evaldas Šlyžius,

Birutė Šlyžienè,

Vaida Lindžiūtè

Department of Animal Breeding and Nutrition, Lithuanian University of Health Sciences,

Tilžès St. 18, LT-47181 Kaunas

Email:evaldas.slyzius@lsmuni.lt

\begin{abstract}
The objective of the paper was to investigate the main factors determining the yield of fat in goat milk in the dairy goat population of Lithuania. The research was carried out on a total of 1,079 dairy goats ( 4 breeds: Czech White Shorthaired $(n=610)$, Saanen $(n=364)$, Lithuanian native $(n=94)$ and Anglo-Nubian (11)) in 7 dairy farms. The average milk yield during lactation was $797.42( \pm 53.3) \mathrm{kg}$. The average milk fat content was $4.14 \%( \pm 0.4)$. The research of the goat milk fat content demonstrated that the indicators investigated in different herds varied. The highest milk fat content in percent was determined among AngloNubian $-5.2 \%$. The milk fat content of all breeds of goats increased with increasing the parity up to the 4-6th parity, respectively, and started decreasing then, after reaching the peak. While assessing the quantity of milk fat during the stage of lactation, the highest milk fat content was determined during the first months $(4.5-4.7 \%)$ and at the end of lactation (4.5\%). The research performed by us showed that such factors as breed, parity, stage of lactation and herd had an impact on the quantity of goat milk fat.
\end{abstract}

Keywords: goat, milk, parity, breed, lactation stage, milk fat

\section{INTRODUCTION}

At the moment, there are over 300 goat breeds on the Earth; they live in all continents excluding Antarctica and are able to adapt to highly varying climatic conditions: from rainforests to parched hot deserts to cold high mountainous regions. More than $80 \%$ of the goats of the world live in Asia and Africa (Hirst, 2017). Goats are raised in order to obtain as much high quality milk, meat and wool produce as possible. Goat milk and meat remain essential products in the continents of Asia and Africa where these animals still are the main source of livelihood for disadvantaged people. Taking into account the fact that over three quarters of the inhabitants of the world live in these continents, goat products are among the most widely used products (Huitema, 2012).
Goat milk and its products are important in everyday nutrition. Goat milk is used to produce butter, kefir, curd, yoghurt, cheese and other products the most popular of which are cheeses of various types. Goat milk is also effective in treating eczemas, migraine, hay fever and constipation. It contains vitamin A, potassium, calcium and phosphorus therefore it is suitable for persons suffering from cardiovascular diseases; as well as vitamins $\mathrm{B} 1, \mathrm{~B} 2$ and $\mathrm{C}$ which increase resistance to various diseases. Goat milk can be consumed by people allergic to cow milk. Proteins contained in milk protect children from diarrhea and take part in all vital processes (Zapasnikienè, 2015).

Lately, a lot of attention has been paid to the composition of goat milk, which is responsible for nutritional and technical characteristics of dairy products. Goat milk mainly consists of 
water $(87.8 \%)$, while the remaining part comprises dry substances (12.2\%). There are plenty of useful mineral substances (sodium, potassium, phosphorus, chlorine, magnesium, iron, zinc, calcium) and vitamins (A, D, E, B1, B2, C, niacin, folic acid, thiamin) in milk. Goat milk contains significantly more $\mathrm{K}, \mathrm{Mg}$ and $\mathrm{P}$ minerals as well as vitamin $\mathrm{A}$ as compared to cow milk (Kumar, 2016; Urbiene, 2015).

Cheese is usually made of milk of small ruminants. The quality of cheese depends on the quantity of fat and proteins. The following proteins can be found in milk: casein, whey proteins, albumin, immunoglobulins, $\beta$-lactoglobulins and $\alpha$-lactoglobulins. Proteins form a colloidal solution in milk. The quantity of proteins in goat milk resembles that in cow milk; however, casein proteins of goat milk are smaller and easier to digest than those of cow milk. Cheese yield depends on the quantity of milk proteins, whereas milk fat affects the stability and texture of dairy products, while the quantity of different fatty acids in cheese determines its taste characteristics. In order to ensure a sufficient amount of fat in milk, the total quantity of dry substances must be increased, the composition of milk must be stabilized and a high fat-protein ratio must be maintained (Kumar et al., 2016).

Milk fat is important for human nutrition; it is contained inside the cells of the human body, it helps strengthening the immune system and participates in metabolic pathways. Fat is also needed in order to meet the energy requirements of the human organism (Urbienè, 2015).

Milk fat is distinguished by a unique structure which is comprised of milk fat globules consisting of a nucleus of triglycerides covered with three layers of phospholipids called the milk fat globule membrane. The milk fat globule membrane consists of phospholipids, sphingolipids, glycolipids, cholesterol and proteins obtained from the endoplasmic reticulum and the epithelial apical membrane of the mammary gland. Milk fat globules are distinguished by size: from a nanometer scale to globules over $15 \mathrm{~mm}$ present in human and cattle milk. However, smaller milk fat globules are found in goat milk: their size varies from 0.53 to $8.58 \mathrm{~mm}$ (Argaman et al., 2016). Omega 3, omega 6 and conjugated linoleic acid present in milk fat are characterized by high nu- tritional value, whereas short-chain fatty acids and unsaturated fatty acids have a positive impact on the human organism. Taste characteristics of the products also depend on the composition of fatty acids (Huitema, 2012).

The results of previous studies have shown that the composition of goat milk depends on the breed (Sung et al., 1999; Argaman et al., 2016), lactation (Antunac et al., 2001; Zervas, 2011), lactation period (Mestawet et al., 2012), feed (Argaman et al., 2016), milking (Ciapepesoni et al., 2004), individual characteristics, environmental conditions and the state of health (Zan, 2006).

The main goal of dairy goat production is to improve traits related with milk performance. One of the most important milk chemical content is fat which can vary for different goat breeds (Ciapepesoni et al., 2004; Mioč et al., 2008) - from 3.25\% (Saanen) to 3.82\% (Czech White Shorthaired). The goat milk fat content significantly differed among lactation stages. G. Ciappesoni et al. (2004), Guler et al. (2007), and T. A. Mestawet et al. (2012) determined that the milk fat content at the beginning and end of lactation was higher than in the middle of lactation. Meanwhile, the researchers' opinions differed in their milk fat content depending on the parity. The research conducted by G. Ciappesoni et al. (2004) and D. Zahraddeen et al. (2007) showed that the milk fat content increased with the increase in the parity, whereas D. Carnicella et al. (2008) and N. Memiši et al. (2011) determined that the milk fat content decreased during each parity. In order to meet the demand, identification of goat breeds with high quality milk components is of great importance because it provides a valuable information for producers and breeders.

The objective of the paper was to investigate the main factors determining the yield of fat in goat milk in the dairy goat population of Lithuania.

\section{METHODS AND CONDITIONS}

The research was carried out on a total of 1,079 dairy goats in 7 dairy farms where only one breed of goats was kept (Lithuanian native - 2 farms, Anglo-Nubian - 2 farms, Czech White Shorthaired - 1 farm, Saanen - 2 farms). 
Goats were kept under similar conditions and were fed the same nutritionally balanced diets in all farms. During the investigation period, goats received feed produced in the farm: pasture grass, hay and oat meal.

The main sources for the analysis were the livestock productivity control data for 2011-2016, as well as the findings of the composition in milk specimen taken from goat holdings. The data of 1,079 goats of 4 breeds (Fig. 1) was analysed: Czech White Shorthaired $(n=610)$, Saanen $(n=364)$, Lithuanian native $(n=94)$, and AngloNubian (11).

The yield of milk was displayed during milking using the Lactocorder ${ }^{\circledast}$ device (Lactocorder ${ }^{\oplus}$ WMB AG, Switzerland). The individual milk yield per lactation was calculated by summing monthly milk yields which were obtained by multiplying daily milk records by the number of days since kidding, for the first period, or by the number of days since the preceding milk recording day for subsequent recording days (Thomas et al., 1999).

Milk samples of $40 \mathrm{ml}$ were individually collected during the morning milking, a preservative sedupol was added, the samples were stored at $4^{\circ} \mathrm{C}$ and transported to the laboratory. In the laboratory fat concentrations were analysed by an infrared spectroscopy Lactoscope FTIR (FT 1.0. 2001; Delta Instruments, Holland) based on the method of absorption of infrared radiation medial region rays; milk testing was performed at the State Enterprise "Pieno Tyrimai".

The State Enterprise "Pieno Tyrimai" operates under the quality management system conforming

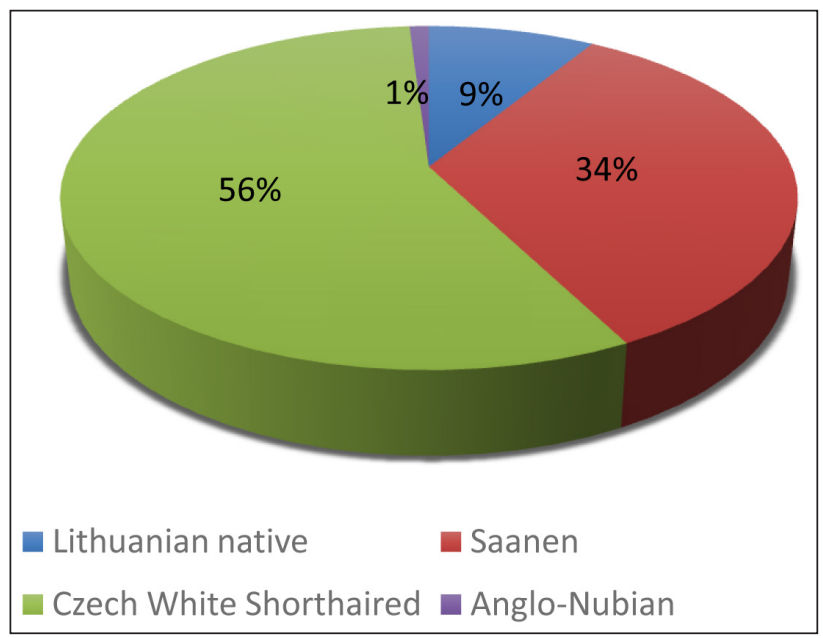

Fig. 1. The distribution of goats by breed to the requirements of the International Standard ISO/IEC 17025:2005 to ensure the accuracy of milk composition and quality tests.

The Lactoscope FTIR is used to measure a specific wavelength absorption of medium infrared rays of fat, proteins and lactose of each component (LST ISO 9622:2000). The principle of the method is the following: after a milk sample is homogenised by an infrared spectrometer, the quantity of absorbed rays is measured: carbonyl groups of ester links of glyceride at an approximate wavelength of $5.7 \mu \mathrm{m}$ (usually marked as filter $\mathrm{A}$ ), and/or $\mathrm{CH}$ groups at an approximate wavelength of $3.5 \mu \mathrm{m}$ (usually marked as filter B) for the determination of the fat quantity; secondary amide groups of peptide links at an approximate wavelength of $6.5 \mu \mathrm{m}$. The concentration of each component is determined by the amount of absorbed infrared rays or water when the wavelength is the same, or milk when the wavelength causes a weak absorption of the component measured. The quantity of these constituents of milk is calculated taking into account the amount of energy absorbed. The quantity of fat in milk is expressed by g/100 g milk.

Statistical data analysis. When analysing the yield of milk fat (\% and $\mathrm{kg}$ ) in the Lithuanian population of dairy goats, the data of goats was divided by the farm ( 7 farms), parity (Anglo-Nubian -4 parities, other goat breeds -7 parities) and the lactation stage (from 1 to 8 months). Different goat's milk fat in kilograms was calculated according to the formula:

\section{Milk Fat kg $=$ Milk kg $\times$ Fat \% / 100.}

The one-way analysis of the variance (ANOVA) was conducted to assess the influence of various factors on milk fat (\% and $\mathrm{kg}$ ) in the Lithuanian population of dairy goats. Average indications $(-X)$, the standard error of means $(\mathrm{Se})$, the coefficient of variation $(\mathrm{Cv})$, and the coefficient of phenotypical correlation $(r)$ between the indications were calculated using the SPSS (Licence No. 9900457; Version 15, SPSS Inc., Chicago, IL) and " $R$ " (The R Project for Statistical Computing, 2012) statistical packages. The one-way analysis of the variance (ANOVA) was conducted to assess the influence of various factors on the quantity of milk fat ( $\%$ and $\mathrm{kg}$ ). 
The model, which was used for evaluation, includes the following fixed factors:

$$
Y_{i j k l}=\mu+B_{i}+H_{j}+L S_{k}+P_{1}+E_{i j k l}
$$

where

$Y_{i j k l}$ is investigated characteristics;

$\mu$ is the overall mean;

$B_{i}$ is the fixed factor 'breed' $(i=1-4)$;

$H_{j}$ is the fixed factor 'herd' $(j=1-7)$;

$L S_{k}$ is the fixed factor 'lactation stage' $(k=1-8)$;

$P_{1}$ is the fixed factor 'parity' $(l=1-70)$;

$E_{i j k l}$ is the random error.

The results are to be considered reliable when $p \leq 0.05$.

\section{RESULTS AND DISCUSSION}

The average milk yield during lactation was $797.42( \pm 53.3) \mathrm{kg}$. The milk fat content in percentage and kilograms was $4.14( \pm 0.4) \%$ and $33.77( \pm 1.9) \mathrm{kg}$, respectively.

The distribution of milk fat ( $\%$ and $\mathrm{kg}$ ) between dairy goats is presented in Figs. 2 and 3. We can see from the data presented (Fig. 2) that milk fat (\%) is equally distributed from the lowest to the highest value and the peak is achieved around the average (4.14\%). The highest number of dairy goats was determined in those classes which are closer to the average (3.5-4.5\%). What concerns the histogram of the fat quantity (kg) (Fig. 3), the highest rates were also determined around the average $(33.77 \mathrm{~kg})$; however, the numbers of goats were not distributed so evenly. This is proved by the $4.73 \%$ higher milk fat $(\mathrm{kg})$ variation coefficient determined.

The conducted analysis of the milk fat content of goats of different breeds in Lithuania (Table 1) shows that the milk fat content is the highest among Anglo-Nubian goats (\%) and Czech White

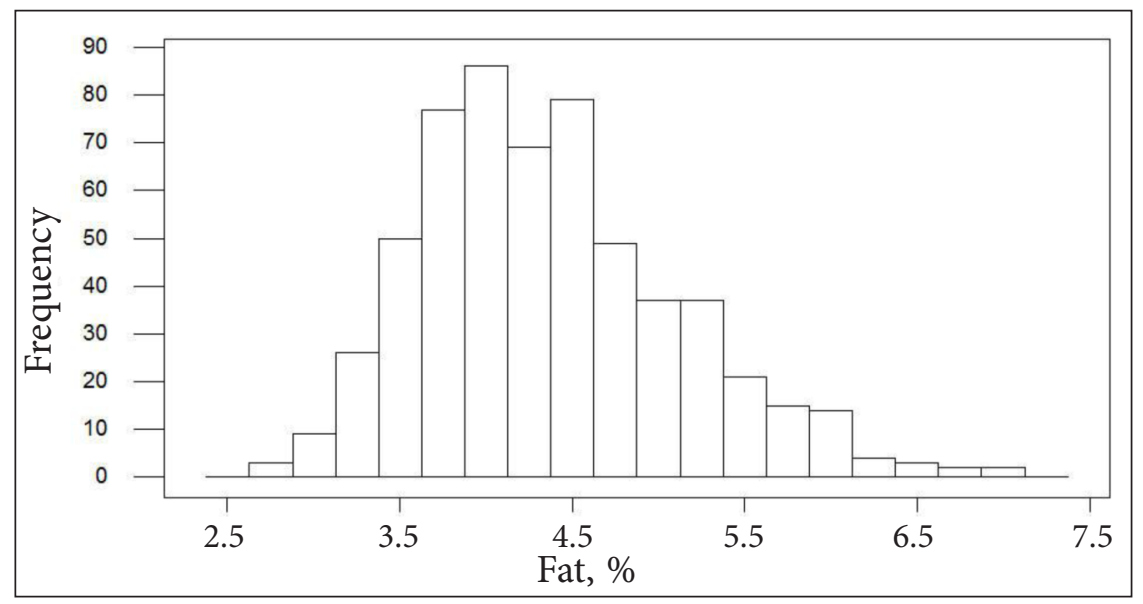

Fig. 2. Distribution of milk fat (percent) among dairy goats

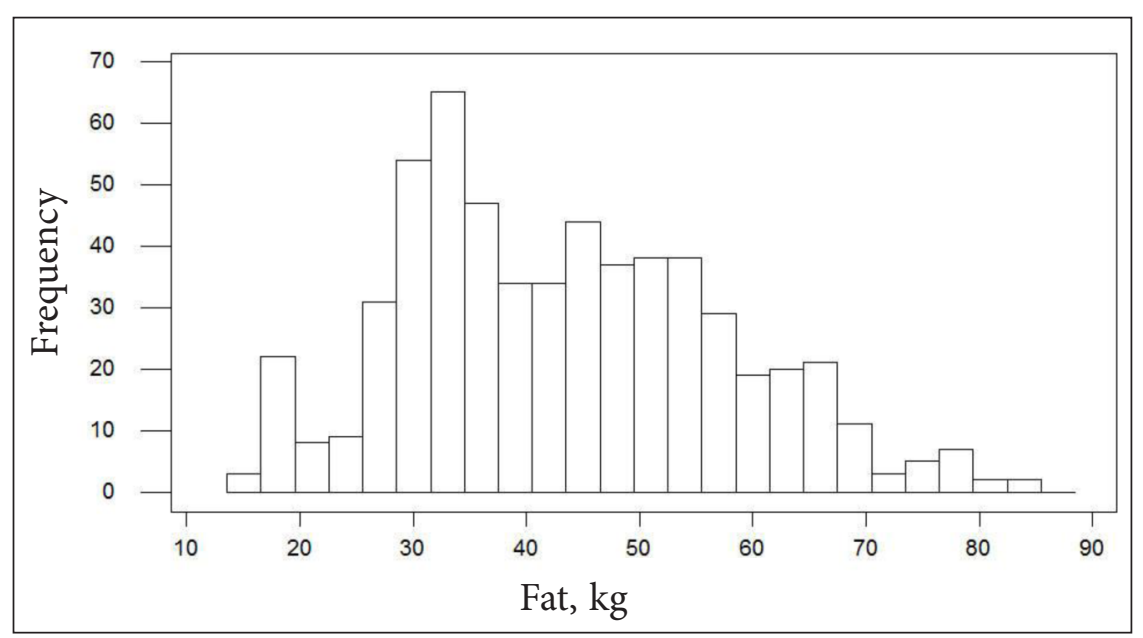

Fig. 3. Distribution of milk fat (kilograms) among dairy goats 
Table 1. Milk fat indicators of different goat breeds

\begin{tabular}{c|c|c|c|c}
\hline Parameters/Breed & $\begin{array}{c}\text { Czech White } \\
\text { Shorthaired }\end{array}$ & Saanen $^{\mathrm{b}}$ & Lithuanian native $^{\mathrm{c}}$ & Anglo-Nubian $^{\mathrm{d}}$ \\
\hline $\begin{array}{c}\text { Amount of milk per } \\
\text { lactation, kg }\end{array}$ & $831.66 \pm 10.11^{* \mathrm{~b}^{* * a} \mathrm{a}}$ & $728.25 \pm 26.22^{* *_{\mathrm{a}} * *_{\mathrm{c}}}$ & $590.74 \pm 42.48^{* *_{\mathrm{a}}^{* * * \mathrm{~b}}}$ & $648.03 \pm 32.33$ \\
\hline Fat, \% & $4.27 \pm 0.04^{* * * \mathrm{~b}}$ & $3.78 \pm 0.07^{* * *_{\mathrm{a}}}$ & $3.84 \pm 0.18$ & $5.2 \pm 0.19$ \\
\hline Fat, $\mathrm{kg}$ & $36.34 \pm 0.69^{* * \mathrm{~b}_{\mathrm{c}}}$ & $27.68 \pm 0.98^{* *_{\mathrm{a}}{ }^{* \mathrm{c}}}$ & $22.62 \pm 1.9^{* *_{\mathrm{a}} \mathrm{b}}$ & $34.99 \pm 0.99$ \\
\hline
\end{tabular}

${ }^{\star} p<0.05 ;{ }^{* *} p<0.01 ;{ }^{* *} p<0.001$.

Shorthaired goats $(\mathrm{kg})$. The said indicators were determined as $1.1 \%$ and $5.79 \mathrm{~kg}$ higher, respectively, than the average of the controlled goat population in Lithuania. The comparison of the indicators of the breeds displayed even more significant differences. The milk fat content (\%) of Anglo-Nubian goats was higher, from $1.13 \%$ (compared to that of Czech White Shorthaired goats) to $1.56 \%$ (compared to that of Lithuanian native goats, $p<0.05)$. Since the quantity of the milk yield of Czech White Shorthaired goats was the highest, a significant difference of milk fat $(\mathrm{kg})$ was also determined as compared to other breeds. The milk fat content $(\mathrm{kg})$ of goats of this breed was higher, from $1.35 \mathrm{~kg}$ (compared to that of Anglo-Nubian goats) to $13.72 \mathrm{~kg}$ (compared to that of Lithuanian native goats, $p<0.05$ ). For the purpose of comparison to the results of our research, Croatian scientists B. Mioč et al. (2008) have determined a very similar milk yield obtained from Saanen goats during lactation $(720 \pm 12.49 \mathrm{~kg}, p<0.05)$ with a lower milk fat content $(3.25 \pm 0.03 \%, p<0.05)$. In the course of the same research, the indicators of Alpine goats were $577.20 \pm 12.49 \mathrm{~kg}$ (milk yield) and $3.47 \pm 0.01 \%$ (milk fat content), $p<0.05$. G. Ciappesoni with a group of researchers (2004) conducted a research of 6,234 Czech White Shorthaired goats. The results of the research revealed a $0.55 \%$ lower milk fat content than that of goats of the same breed investigated by us. During the research of four breeds of goats (Mamber, Damascus, Alpine-Mamber cross and Alpine-Damascus cross) conducted by Israeli scientists N. ArgovArgaman et al. (2016), it was determined that the quantity of milk of local goats during lactation was by $44 \%(p<0.001)$ lower as compared to that of Alpine crossbred. It was determined during the research conducted by us that the milk yield of Lithuanian native goats was 29.92\% $(p<0.05)$, whereas the quantity of milk fat was by $33.02 \%$ $(p<0.05)$ lower than that of imported breeds of goats.

The analysis of the milk fat content ( $\%$ and $\mathrm{kg}$ ) in goats at different parities conducted by breeds showed that, having compared the goat milk fat content in percent (Fig. 4), it was higher

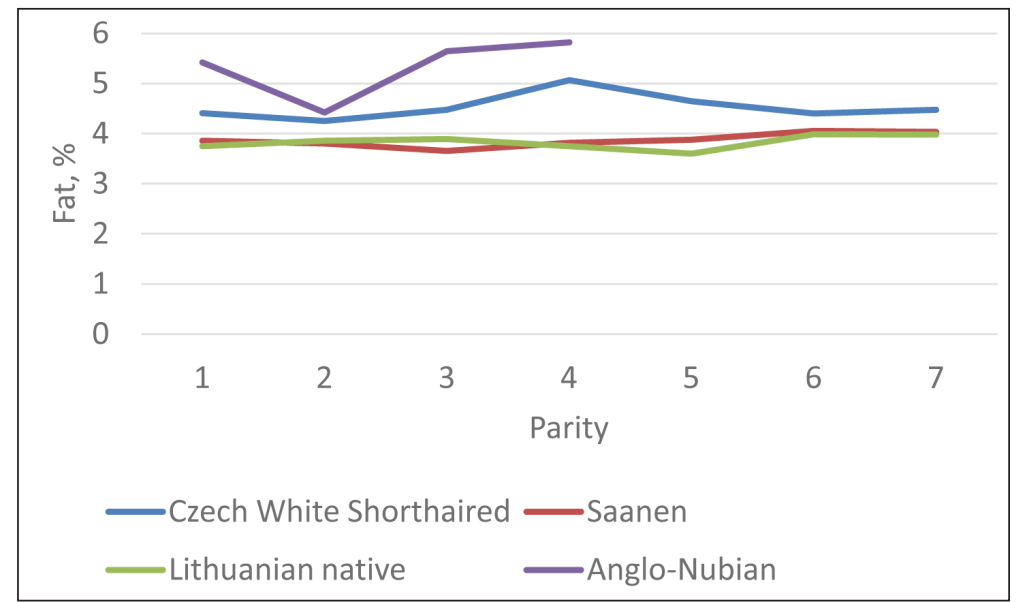

Fig. 4. Different parity goat milk fat content in percent 
in the case of Anglo-Nubian goats than that of all other breeds during all parities. The milk fat content of Anglo-Nubian goats increased with the increase in the parity. This parameter of Czech White Shorthaired goats increased until the 4th parity and decreased during the following parities after it reached the peak (5.07\%). However, it was observed that even the lowest indicator (2nd parity, $4.2 \%$ ) was not poor. The milk fat content of Saanen goats varied less and reached the peak during the 6 th parity (4.1\%). Analogous trends were determined after the comparison of the milk fat quantity (kg) (Fig. 5) of different breeds during parities.

Similar results were also obtained by Croatian scientists B. Mioč et al. (2008) who determined that the highest milk fat content was that of goats of the 5th and higher parities $(3.47 \pm 0.02 \%)$, though significant differences were not observed among goats of all parities: it fluctuated from $3.42 \pm 0.02 \%$ (the third parity) to $3.47 \pm 0.02 \%$ (the fifth and higher parities), respectively. During the research conducted by G. Ciappesoni et al. (2004), a slight increase of the milk fat content was established depending on lactation (from $3.52 \%$ during the first parity to $3.55 \%$ during the fourth and further parities, $p<0.05)$. Nigerian scientists D. Zahraddeen et al. (2007) determined that the fat content was highest in the third parity $(5.54 \pm 0.03 \%)$ followed by the second parity $(4.73 \pm 0.03 \%)$ and least in the first parity $(4.39 \pm 0.02 \%)$, whereas D. Carnicella et al. (2008) determined that an insignificant but statistically higher $(0.1 \%(p<0.001))$ milk fat content was in the case of goats of the first parity as compared to that of goats of the second, third and further parities. Serbian scientists N. Memiši et al. (2011) also determined that the milk fat content decreased during each parity from $3.40 \pm 0.12 \%$ in the first to $3.24 \pm 0.22 \%$ in the fourth parity.

Having conducted the analysis of the goat milk fat content during the stage of lactation (Fig. 6), a significant change in the milk fat content depending on the month of lactation was determined. The highest milk fat content was determined during the first months of lactation (average: from 4.5 to $4.7 \%$ ), it decreased to $3.7 \%$ (average) in the middle of lactation and then started increasing again during the last months of lactation in all goat breeds. Such results can be explained by the fact that the goat milk yield at the beginning and end of lactation is lower than in the middle of lactation and this indicator correlates negatively with the milk fat content for most breeds. Analogous results were obtained by Croatian scientists B. Mioč et al. (2008) who investigated the milk fat content during the course of lactation and determined that the milk fat content at the beginning $(3.48 \pm 0.008 \%, p<0.05)$ and the end $(3.71 \pm 0.01 \%, p<0.05)$ of lactation was higher than in the middle of lactation $(3.36 \pm 0.009 \%, p<0.05)$. Having examined the milk fat content of Damascus goats during the stage of lactation, Guler et al. (2007) determined that the milk fat content at the beginning $(4.85 \pm 0.25 \%, p<0.05)$ and end $(4.40 \pm 0.1 \%$, $p<0.05)$ was higher than in the middle of lactation

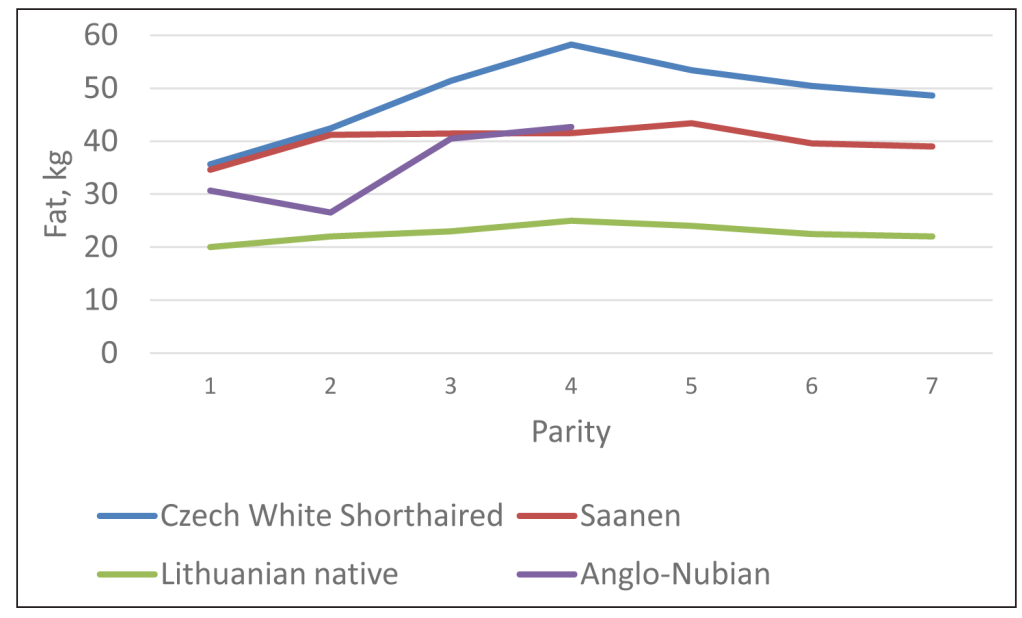

Fig. 5. Different parity goat milk fat content in kilograms 


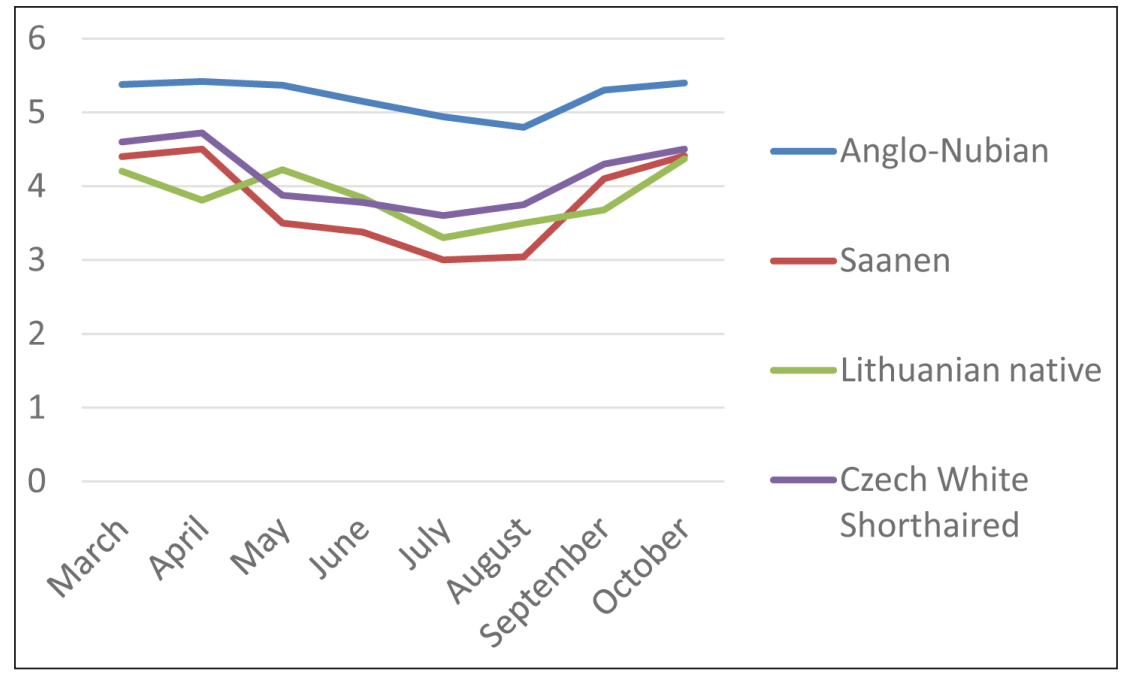

Fig. 6. Goat milk fat during the lactation stage

(3.75 $\pm 0.45 \%, p<0.05)$. G. Ciappesoni et al. (2004) and T. A. Mestawet et al. (2012) also determined that the milk fat content at the beginning and end of lactation was higher than in the middle of lactation. Nigerian scientists D. Zahraddeen et al. (2007) established that the fat content decreased as lactation progressed. The fat content during the colostrum period, the early, mid and end of lactation were $5.35 \pm 0.03,4.97 \pm 0.03$, $4.62 \pm 0.03$ and $4.13 \pm 0.03 \%$, respectively. The wet season had a higher fat content $(5.04 \pm 0.02 \%)$ than the dry season $(4.49 \pm 0.12 \%)$.

The indicators of the milk fat content ( $\%$ and $\mathrm{kg}$ ) of different herds are presented in Table 2. The data analysis conducted showed that the indicators investigated in different herds varied considerably. The milk fat content in the herds ranged from $3.41 \pm 0.13$ to $4.54 \pm 0.03 \%$ and from $20.27 \pm 1.65$ to $46.86 \pm 0.66 \mathrm{~kg}$. It is known that usually one breed of goats is kept in different herds; therefore, the fact that the influence of the breed of goats on the quantity of milk fat is significant can be confirmed. The results of the research conducted by us were also supported by Italian scientists M. Decandia et al. (2007), who conducted a research of 113 goats in 3 farms and determined a statistically reliable difference of milk fat in the farms (from 4.06 to $4.52 \%, p<0.05$ ), and by D. Kučevič et al. (2016), who conducted a research of 72 French Alpine goats in three farms (milk fat from $3.08 \pm 0.42 \%$ to $4.16 \pm 0.93 \%, p<0.05$ ).

The correlation analysis of milk yield and the indicators of parity and milk fat (Table 3) demonstrated that a positive correlation of the parity and milk fat quantity $(\mathrm{kg})$ was determined in the case of Czech White Shorthaired goats $(r=0.386$, $p<0.01)$; however, this correlation was negative in the case of Lithuanian native goats $(r=-0.414$, $p<0.01)$. Nigerians scientists D. Zahraddeen et al. (2007) determined that the percentage of fat content in the present study decreased significantly with advances in the parity. This contrasts with an earlier report by F. Beyene and E. Seifu (2005) who observed a significant increase in the fat content of Borana goat with parity.

A statistically reliable negative correlation of the milk quantity and milk fat percentage $(r=-0.237, p<0.05)$ of Saanen goats confirms the results of the researches conducted by foreign scientists (Zahraddeen et al. (2007) and Mioč et al. (2008)) showing that the correlation of the milk quantity and milk fat is negative for most breeds.

Table 2. Goat milk fat indicators in different herds

\begin{tabular}{c|c|c|c|c|c|c|c}
\hline \multirow{2}{*}{ Parameters } & \multicolumn{7}{c}{ Herd } \\
\cline { 2 - 9 } & $\mathbf{1}$ & $\mathbf{2}$ & $\mathbf{3}$ & $\mathbf{4}$ & $\mathbf{5}$ & $\mathbf{6}$ & $\mathbf{7}$ \\
\hline Fat, \% & $4.54 \pm 0.03$ & $3.95 \pm 0.12$ & $3.98 \pm 0.08$ & $3.41 \pm 0.13$ & $4.00 \pm 0.09$ & $3.78 \pm 0.14$ & $3.85 \pm 0.09$ \\
\hline Fat, kg & $46.86 \pm 0.66$ & $45.70 \pm 1.02$ & $27.64 \pm 1.16$ & $20.27 \pm 1.65$ & $28.92 \pm 0.46$ & $40.33 \pm 5.78$ & $29.00 \pm 1.00$ \\
\hline
\end{tabular}


Table 3. Correlation analysis

\begin{tabular}{|c|c|c|c|}
\hline \multicolumn{2}{|c|}{ Parameters } & Milk yield, kg & Parity \\
\hline \multirow{2}{*}{ Czech White Shorthaired } & Fat, $\%$ & $0.242^{\star \star}$ & 0.087 \\
\hline & Fat, kg & $0.866^{* *}$ & $0.386^{\star *}$ \\
\hline \multirow{2}{*}{ Saanen } & Fat, $\%$ & $-0.237^{\star *}$ & $0.142^{\star *}$ \\
\hline & Fat, kg & $0.862^{\star *}$ & $0.099^{*}$ \\
\hline \multirow{2}{*}{ Lithuanian native } & Fat, \% & $-0.205^{\star}$ & 0.070 \\
\hline & Fat, kg & $0.882^{\star *}$ & $-0.414^{* *}$ \\
\hline \multirow{2}{*}{ Anglo-Nubian } & Fat, \% & -0.084 & 0.170 \\
\hline & Fat, kg & $0.682^{*}$ & -0.114 \\
\hline
\end{tabular}

${ }^{\star} p<0.05 ;{ }^{* *} p<0.01$

D. Zahraddeen et al. (2007) determined a negative correlation between the milk fat and milk yield. This implies that selection for milk yield will invariably reduce concentrations of milk fat. The research conducted by B. Mioč et al. (2008) and E. Bagnicka and M. Lukaszewicz (1999) also demonstrated a negative correlation of the milk quantity and milk fat content, respectively, $r=-0.24(p<0.05)$ and $r=-0.11(p<0.01)$. However, this correlation (milk yield and fat percentage) is not very significant but positive ( $r=0.242$, $p<0.01)$ among Czech White Shorthaired goats in Lithuania; therefore, it can be maintained that an increase in the milk quantity of goats of this breed does not reduce the milk fat content.

The fat content was significantly $(p<0.001)$ affected by all the factors (breed, parity, stage of lactation and herd) investigated (Table 4). It was determined that the breed influenced the variation of percentage and $\mathrm{kg}$ of the milk fat content statistically reliably (from 8.68 to $9.8 \%$, $p<0.0001)$. T. A. Mestawet with a group of scientists (2012) conducted a research involving four breeds of goats (Arsi-Bale, Somali, ToggenburgArsi-Bale cross and Boer) in Ethiopia and determined a significant difference of the milk fat content among the breeds (from 3.65\% in the case of
Cross to $5.15 \%$ in the case of Arsi-Bale, $p<0.01$ ). D. Zahraddeen et al. (2007), and K. Piliena and D. Jonkus (2012) also established a statistically reliable influence of the breed on the goat milk fat content $(p<0.001)$. Having assessed the influence of non-genetic factors, it was found that the lactation and the month of lactation significantly influenced the percentage of milk fat from 28.42 to $34.57 \%, p<0.0001$. Similar results were achieved by other authors (Carnicella et al., 2008; Mioč et al., 2008; Memiši et al., 2011). In concordance with other authors (Decandia et al., 2007; Kučevič et al., 2016), the effect of herd was observed (from $13.42 \%$ (milk fat \%) to $27.44 \%$ (milk fat kg), $p<0.0001$ ).

\section{CONCLUSIONS}

The research of the goat milk fat content demonstrated that the indicators investigated in different herds varied. The highest milk fat content in percent was determined among Anglo-Nubian (5.2\%) and in kilograms among Czech White Shorthaired $(36.34 \mathrm{~kg})$ goats. The milk fat content of all breeds of goats increases with increasing the parity up to the 4-6th parity, respectively, and starts decreasing then, after reaching

Table 4. Influence of various factors on the milk fat indicators

\begin{tabular}{c|c|cc}
\hline Factors & Number of classes & Fat, \% & Fat, kg \\
\hline Breed & 4 & 9.8 & 8.68 \\
\hline Herd & 7 & 13.42 & 27.44 \\
\hline Parity & 7 & 28.42 & 19.24 \\
\hline Lactation stage & 8 & 34.57 & 20.19 \\
\hline
\end{tabular}

$p<0.0001$. 
the peak. While assessing the quantity of milk fat during the stage of lactation, the highest milk fat content was determined during the first months (4.5-4.7\%) and at the end of lactation (4.5\%). The correlation analysis of the milk quantity of different breeds and the indicators of parity and milk fat demonstrated a positive correlation of the parity and the quantity of milk fat $\mathrm{kg}$ among Czech White Shorthaired $(r=0.386, p<0.01)$ and a negative correlation of the milk yield and the fat content in percent among Saanen $(r=-0.237$, $p<0.01)$ and Lithuanian local goats $(r=-0.205$, $p<0.05)$, whereas this correlation was positive among Czech White Shorthaired goats $(r=0.242$, $p<0.01)$. The research performed by us showed that such factors as breed, parity, stage of lactation and herd had an impact on the quantity of goat milk fat.

\section{ACKNOWLEDGEMENTS}

The study was financed by the Ministry of Agriculture of the Republic of Lithuania in the framework of the ongoing research and development of agriculture, food industry and fisheries in the 2015-2020 period: Determination of Milk Fat Genetic Content Factors in the Lithuanian Dairy Goat Population, No. MT - 16-15.

Received 2 August 2017 Accepted 23 October 2017

\section{REFERENCES}

1. Antunac N., Samaržija D., Havranek J. L., Pavić V., Mioč B. 2001. Effects of stage and number of lactation on the chemical composition of goat milk. Czech Journal of Animal Science. Vol. 46. No. 12. P. 548-553.

2. Argov-Argaman N., Hadaya O., Glasser T., Muklada H., Dvash L., Mesilati-Stahy R., Landau S. Y. 2016. Milk fat globule size, phospholipid contents and composition of milk from purebred and Alpine-crossbred Mid-Eastern goats under confinement or grazing condition. International Dairy Journal. Vol. 58. P. 2-8.

3. Bagnicka E., Łukaszewicz M. 1999. Genetic and environmental variation of dairy traits in Polish goats. Animal Science Papers and Reports. Vol. 17. No. 1. P. 59-65.

4. Beyene F., Seifu E. 2005. Variations in Quality and Fermentation Properties of Milk from Local Goats. Langston University Goat Research Extension [cited 2017-05-21]. Available from: http://www2. luresext.edu/international/MilkFermProp.htm

5. Carnicella D., Dario M., Ayres M. C. C., Laudadio V., Dario C. 2008. The effect of diet, parity, year and number of kids on milk yield and milk composition in Maltese goat. Small Ruminant Research. Vol. 77. Issue 1. P. 71-74.

6. Ciappesoni G., Přibyl J., Milerski M., Mareš V. 2004. Factors affecting goat milk yield and its composition. Czech Journal of Animal Science. Vol. 49. P. 465-473.

7. Decandia M., Cabiddu A., Molle G., Branca A., Epifani G., Pintus S., Tavera F., Piredda G., Pinna G., Addis M. 2007. Effect of different feeding systems on fatty acid composition and volatile compound content in goat milk. Options Méditerranéennnes. Vol. 74. P. 129-134.

8. Guler Z., Keskin M., Masatcioglu T., Gul S., Bicer O. 2007. Effects of breed and lactation period on some characteristics and free fatty acid composition of raw milk from Damascus goats and German Fawn $\times$ Hair goat B1 crossbreds. Turkish Journal of Veterinary and Animal Sciences. Vol. 31. No. 5. P. 347-354.

9. Hirst K. K. 2017. The Domestication History of Goats [cited 2017-05-21]. Available from: http:// archaeology.about.com/od/domestications/qt/ goats.htm

10. Huitema N. A. 2012. How Nutritional and Genetic Factors Affect New Zealand Goat Milk Composition. New Zealand: University of Waikato Hamilton. P. 3-11 [cited 2017-05-25]. Available from: http://researchcommons.waikato.ac.nz/handle/10289/6525

11. Kučević D., Pihler I., Plavšić M., Vuković. 2016. The composition of goat milk in different types of farmings. Biotechnology in Animal Husbandry. Vol. 32. No. 4. P. 403-412.

12. Kumar A. Y., Jitendra S., Kumar Y. S. 2016. Composition, nutritional and therapeutic values of goat milk: A review. Asian Journal of Dairy \& Food Research. Vol. 35. Issue 2. P. 96-102.

13. Memisi N., Bogdanović V., Žujović M., Tomić Z. 2011. Influence of order of lactation on milk production and somatic cell count in Alpine goats. Biotechnology in Animal Husbandry. Vol. 27. Issue 2. P. 227-234.

14. Mestawet T. A., Girma A., Ådnøy T., Devold T. G., Narvhus J. A., Vegarud G. E. 2012. Milk production, composition and variation at different lactation stages of four goat breeds in Ethiopia. Small Ruminant Research. Vol. 105. P. 176-181.

15. Mioč B., Prpić Z., Vnučec I., Barać Z., Sušić V., Samaržija D., Pavic V. 2008. Factors affecting goat milk yield and composition. Mljekarstvo. Vol. 58. Issue 4. P. 305-313.

16. Piliena K., Jonkus D. 2012. Factors Affecting Goat Milk Yield and Its Composition in Latvia. Research for Rural Development 2012: 18th Annual 
International Scientific Conference Proceedings. Vol. 1. P. 79.

17. Sung Y. Y., Wu T. I., Wang P. H. 1999. Evaluation of milk quality of Alpine, Nubian, Saanen and Toggenburg breeds in Taiwan. Small Ruminant Research. Vol. 33. No. 1. P. 17-23.

18. Thomas D. L., Berger Y. M., Mckusick B. C. 1999. Milk and lamb production of East-Friesian-cross ewes in the northcentral United States. In: Milking and Milk Production of Dairy Ewe and Goats. EAA. Publication No. 95. Eds. F. Barillet, N. P. Zervas. Wageningen, The Netherlands: Wageningen Pers. P. 474-477.

19. Urbienè S. 2015. Pieno ir jo sudedamuju daliu biologine reikšmé. Kaunas: Akademija. 199 p.

20. Zahraddeen D., Butswat I. S. R., Mbap S. T. 2007. Evaluation of some factors affecting milk composition of indigenous goats in Nigeria. Livestock Research for Rural Development. Vol. 19. Issue 11 [cited 2017-03-20]. Available from: http://www. lrrd.org/lrrd19/11/zahr19166.htm

21. Zan M., Stibilj V., Rogelj I. 2006. Milk fatty acid composition of goats grazing on alpine pasture. Small Ruminant Research. Vol. 64. Issue 1. P. 45-52.

22. Zapasnikienè B. 2015. Kaip auginti ožką. Baisogala: Liucijus. $60 \mathrm{p}$.

23. Zervas G., Tsiplakou E. 2011. The effect of feeding systems on the characteristics of products small ruminants. Small Ruminant Research. Vol. 101. Issues 1-3. P. 140-149.

\section{Evaldas Šlyžius, Birutė Šlyžienè, Vaida Lindžiūtė}

\section{VEIKSNIAI, LEMIANTYS OŽKỤ PIENO RIEBUMA}

Santrauka

Darbo tikslas - ištirti pagrindinius ožkų pieno riebalų kiekị lemiančius veiksnius Lietuvos pieninių ožkų populiacijoje. Tyrimas atliktas septyniuose ūkiuose su keturių veislių (Čeku baltosios $(n=610)$, Zaaneno $(n=364)$, Lietuvos vietinès $(n=94)$ ir Anglų Nubijos (11)) ožkomis. Tyrimo metu nustatytas vidutinis visų veisliu ožkų primelžto pieno kiekis per laktaciją - 797,42 $( \pm 53.3) \mathrm{kg}$, jo riebumas - 4,14 $( \pm 0,4) \%$. Ožkų pieno riebumo tyrimai parodé, kad skirtinguose ūkiuose rodikliai įvairuoja. Nustatytas didžiausias Anglų Nubijos veislès ožkų pieno riebumas procentais $-5,2 \%$. Visų veislių ožkų pieno riebumas didèjo atitinkamai iki 4-6 laktacijos, o pasiekęs piką pradėjo mažeti. Vertinant pieno riebalų kiekị per laktaciją nustatytas aukščiausias riebumas pirmaisiais laktacijos mènesiais $(4,5-4,7 \%)$ ir laktacijos gale (4,4 \%). Mūsu atlikti tyrimai parodè, kad veislè, laktacijos periodas, laktacija ir ūkis turèjo ịtakos ožkų pieno riebalų kiekiui.

Raktažodžiai: ožkos, pienas, laktacija, veislè, laktacijos mènuo, pieno riebalai 